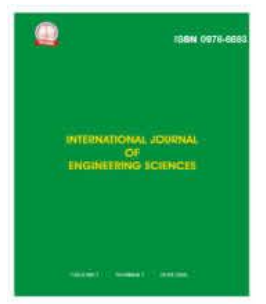

\title{
International Journal of Engineering Sciences
}

(ISSN 0976- 6693)

Volume 12 Number 2 July 2019

(Special Issue on Applications in Management and Social Sciences)

\section{Research papers}

ES120201 The Onset of Civil War: Combining Various Scholarly Research

Sugumaran Narayanan

ES120202 How Algerian sociology turned his back to applied researches?

Faradji Mohamed Akli

ES120203 When poverty knocks on the door: Sharing the story of low income

$50-56$ single mothers in Kelantan

$$
\begin{gathered}
\text { Zarina Md Nor, Nur Zhafirah Mohamad, Suresh Kumar N } \\
\text { Vellymalay }
\end{gathered}
$$

ES120204 Diversification as a Means of Achieving Sustainable Development

Goal on Poverty Eradication:

Evidence from Farm Households, Rural Nigeria

Abdulaziz Shehu, Shaufique F. Sidique

ES120205

Hong Kong Petroleum Stock Pricing Model

$67-72$

William Lau 